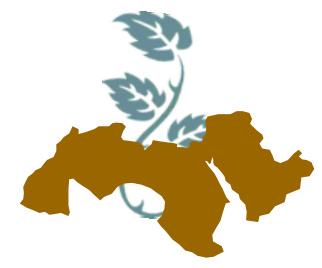

\title{
EFFECT OF BARLEY FLOUR ON WHEAT BREAD QUALITY
}

\author{
El-Taib, H.I.; I.R.S.A. Rizk; E.I. Yousif and Amal A. Hassan \\ Food Science Dept., Fac. of Agric., Ain Shams Univ., Cairo, Egypt
}

Keywords: Wheat flour, Barley flour, Rheologyical properties, Pan bread, Sensory evaluation.

\section{ABSTRACT}

This study was carried out to investigate the possibility of utilization of barley flour in production of pan bread. wheat flour of (72\% extract) was replaced by 10,15 and $20 \%$ barley flour. The effect of such replacements on physical and chemical characteristics of produced pan bread were studied. The results indicated that barley flour had a higher contents of chemical composition than that in wheat flour except carbohydrate content was the highest in wheat flour $(85.53 \%)$ than in barley flour (76.67\%), whereas, protein, ash, dietary fiber, $\beta$-glucan and antioxidant were higher content in barley flour $(13.63,2.44,19.00,8.65$, 97.34 respectively) as compared with its content in wheat flour $(12.26,0.49,4.88,0.34,55.33$ respctively), while, wet gluten and falling number were reduced by added barley in composite flour. The rheological properties of the five dough mixes were studied using farinograph and extensograph. The water absorption and dough weakening increased as the percentage of barley flour increased, while were decreased the extensibility and maximum resistance to extension. The results of sensory characteristies of prepared bread (containes $10 \%$ barley flour) was not significants different from control for crust color, grain and texture.

The results revealed that it was possible to use barley flour at level of $10,15 \%$ to produce bread that satisfied baker's and consumer's sensory expectation. This levels may be to increased the nutritional value from dietary fibers, $\beta$-glucan, minerals, vitamins and antioxidants.

\section{INTRODUCTION}

Wheat (Triticum aestivum) is the most important crop for baking due to its absolute baking performance in comparison to all other cereals (Dewettinck et al 2008). Several developing countries have encouraged the initiation of programs to evaluate the feasibility of alternative locally available flours as a substitute for wheat flour. Many efforts have been carried to promote the use of composite flours, in which a portion of wheat flour is replaced by locally growing crops, to be used in bread, thereby decreasing the cost associated with imported wheat (Olaoya et al 2006). However, wheat flour proteins are deficient in some essential amino acids such as lysine lowering the quality and nutritional properties of cereal and their products (Dhingra and Jood, 2001).

Barley is well known as an excellent choice for diet fortification in deficient proteins areas (Aludatt et al 2012). Newman and Newman (2006) have used barley in several food industries such as the brewing industry and even animal feeding. Recently several studies were recommended to use barley seed in the human diet compared to other seeds due to pharmaceutical and neutraceutical properties (Manach et al 2004). Many diseases were studied in relation to barley and its products such as cardiovascular disease and diabetes (Lupton et al 1994). Blending of barley with human diets is being intensively studied due to the presence of $\beta$-glucan and phenolic compounds which have the potential to lower cholesterol and glucose levels in blood (Cavallero et al 2002). Miller (1994) showed that the isolated $\beta$-glucan from barley reduced glucose and insulin response to carbohydrates loads in human. Barley proteins have been recognized as a rich source of the limiting essential amino acids (Lysine, threonine, methionine and tryptophan) (Newman and Newman 2006).

Bread is an important stable food in both developed and developing countries, wheat flour of both hard and soft wheat classes has been the major ingredient of leavened bread for many years 
because of its functional properties (Abdelghafar et al 2011).

Therefore, this work was aimed to study the proximate chemical composition of wheat and barley flour and the effect of the partial replacement of wheat flour by barley flour on physical properties of the resulted dough. Baking characteristics of pan bread prepared from the different suggested replaced flours were also evaluated.

\section{MATERIALS AND METHODS}

\section{MATERIALS}

Strong Wheat flour (72\% extraction) was obtained from Ebnel-Khattab milling company in $6^{\text {th }}$ October, Cairo, Egypt. Barley grains, hull less barely grains (Hordium vulgare L.) was obtained from Barley Research Section, Field Crops Research Institute, Agricultural Research Center, Giza, Cairo, Egypt.

All other ingredients (Instant active dry yeast, sucrose, salt, corn oil and bread improver) were obtained from the local market, Cairo, Egypt.

\section{Methods}

\section{Preparation of barley flour}

Hull less barley grains were moistened to $14 \%$ moisture content for $24 \mathrm{~h}$, then milled by perten laboratory mill 3100 to whole barley flour, then sieved through a 35-mesh screen sieve to produce flour $85 \%$ extraction rate. The flour was packed in polyethylene bags and stared at $\left(-18^{\circ} \mathrm{C}\right)$ until used.

\section{Preparation of composite flour blends}

Wheat flour (72\% ext.) was partially replacement with different ratio by $10,15,20,25$ and $30 \%$ of barley flour. The flour mixtures were individually blended, homogenized, then packed in polyethelene bags which tightly closed and stored at $\left(-18^{\circ} \mathrm{C}\right)$ until used.

\section{Pan bread processing}

The conventional straight-dough method for pan bread was performed according to the procedure developed by A.A.C.C. (2000) with some modification. The following formulation: flour $100 \mathrm{~g}$, sugar $0.5 \mathrm{~g}$, yeast (Active dry yeast) $2.0 \mathrm{~g}$, salt (sodium chloride) $2.0 \mathrm{~g}$, corn oil $0.5 \mathrm{~g}$ and specific amount of water according to the water absorption revealed by Brabander Farinograph.

\section{Analytical methods}

\section{Chemical analysis}

Moisture content, crude protein ( $\mathrm{N} \times 5.7$ ), lipids, ash and crude fiber contents were determined according to A.O.A.C. (2000). Nitrogen free extract (NFE) was calculated by difference. Also, vitamins and minerals content were determined according to A.O.A.C. (2000).

Amino acids analysis for both, essential and non-essential amino acids were estimated using automatic high performance amino acid analyzer at Regional center for food\&feed, Cairo,Egypt. According to the method described by Baxter (1996). A $0.1 \mathrm{~g}$ of sample was hydrolyzed using 1 $\mathrm{ml}$ of $6 \mathrm{~N} \mathrm{HCl}$, then the sample was placed in distillation refluxing unit $(100 \mathrm{C} / 24 \mathrm{~h})$ under vacuum. The supernatant was filtered with cheese cloth followed by lyophilization and stored at -18C for further amino acid analysis.

Protein quality of the various flours and flour blends.

The protein quality was evaluated using the following parameters:

Chemical score of essential amino acid (EAA) relative to FAO / WHO scoring pattern (1973) using the following equation:

\section{Chemical score \% (CS)}

$$
=\frac{E A A \% \text { in crude protein } x 100}{E A A \% \text { of FAO } / \text { WHO scoring pattern }}
$$

The lowest percentage had been taken as the chemical score, and the corresponding amino acid had been taken as the limiting amino acid.

\section{Essential amino acid index (EAAI)}

EAAI had been calculated according to Oser (1959) as the geometric mean of the ratios of essential amino acids in the crude protein relative to their respective amount in FAO / WHO scoring pattern (1973) as percentage

Biological value (BV): was calculated according to Oser (1959) using the following equation: 


$$
B V=1.09(E A A I)-11.73
$$

Calculated protein efficiency ratio (C.PER): was calculated according to Al-Smyer et al (1974) using the following equation:

PER=-1.816+0.435 (Methionine)+0.78 (Leucine)+ 0.211 (Histidine) - 0.944 (Tryosine).

Total phenolic and flavonoid contents were determined according to methods described by Zilic et al (2012). But free radical scavenging activity were determined using the stable diphenyl picryl hydrzyl (DPPH) according to Hwang and Dothi (2014).

Total dietary fiber were measured according to the method described by A.O.A.C. (2000). Soluble and insoluble dietary fibers were determined according to the method described by Prosky et al (1998). B-glucan was determined to the method described by Carr et al (1990).

Wet gluten and falling No. of wheat flour sample $(72 \%$ ext.) and wheat flour samples replacement with different ratio by barley flour were determined according to the method described in A.A.C.C. (2000),

\section{Rheological properties}

Dough rheological properties of the various flour and flour dough blends were determined by Brabender farinograph and extensograph instruments according to A.A.C.C. (2000).

Physical characteristics and organoleptic evaluation of pan bread

The weight and pan bread volume was measured by rape seed displacement method as described by A.A.C.C. (2000) specific volume were calculated by dividing the volume $\left(\mathrm{cm}^{3}\right)$ by their weight $(\mathrm{g})$. Organoleptic evaluation (crust color, summitry of form, grain, crumb color and texture) was determined according to the method described by Maiya et al (2013).

\section{Texture properties of bread crumb}

Texture parameters (hardness, springiness, cohesiveness, gumminess and chewiness) of bread sample were measured by using a texture analyzer TA-CT3 (Brookfield, USA) as adopted by the standard method by A.A.C.C., method 74-09 A.A.C.C. (2000).

\section{Statistical analysis}

The results were statistically analyzed by SPSS computer software (SPPS, 2000). The stataistical was performed by analysis of variance (ANOVA) and significant differences among the means established was contented using Duncan's multiple test at $(\mathrm{P}<0.05)$ according to Waller and Duncan (1969)

\section{RESULTS AND DISCUSSION}

\section{Chemical properties of wheat and barley flour}

Proximate chemical composition of wheat flour (72\% ext.) and barley flour are presented in Table (1). Barley flour was significantly higher protein, lipids, ash and crude fiber being $13.63 \%, 3.18 \%$, $2.77 \%$ and 4.53 , respectively.Meanwhile, wheat flour significantly contained the higher percentage of nitrogen free extract. These results are in agreement with Salem (2005) and El-Yamlahi and Quhssine (2013). Also, from the results presented in Table (1), it could be noticed that, barley flour significantly contained higher vitamins (Thiamine, Riboflavin and Tocopherols) by 500, 184 and $350 \%$ more than wheat flour, respectively for these vitamins. Also, it could be noticed that barley flour recorded the higher content of $\mathrm{Na}, \mathrm{K}, \mathrm{Fe}, \mathrm{P}$, $\mathrm{Zn}, \mathrm{Mn}$ and $\mathrm{Mg}$ compared to wheat flour. These results agreed with those obtained by Mekhael (2005).

The investigated wheat and barley flour were analyzed for total dietary fiber (TDF), soluble dietary fiber (SDF), insoluble dietary fiber (IDF) and $\beta$ glucan. Results are show in Table (1). Barley flour contained the higher percentage of TDF, SDF, IDF and $\beta$-glucan compared with wheat flour (72\% ext.) by $130,480,390$ and $8.65 \%$ more than wheat flour, respectively. Those results are in accordance with those obtained by Mekhael (2005) and Mann et al (2005). Also, data in Table (1) showed that, total phenolic contents were higher significantly in barley flour compared to wheat flour (12,58 ver $1.13 \mathrm{mg}$ gallic/g). On the other hand, no significantly differences between their flavonoid contents. These results are in agreement with Quinde-Axtell and Baik (2006).

The results of antioxidant activity as shown in Table (1) revealed that barley flour had significantly high antioxidant activity (97.34 mg trolox/g) 
compared with wheat flour (55.33 $\mathrm{mg}$ trolox $/ \mathrm{g}$ ). These results are in harmony with those obtained by Aludatt et al (2012) and Zhao et al (2008).

Table 1. Chemical properties (chemical composition, vitamins, minerals, dietary fiber, $\beta$-glucan, phytochemical and antioxidant activity of wheat and barley flour (\% on dry weight basis).

\begin{tabular}{|c|c|c|}
\hline Parameters & $\begin{array}{c}\text { Wheat flour } \\
\text { (72\% ext.) }\end{array}$ & $\begin{array}{l}\text { Barley } \\
\text { flour }\end{array}$ \\
\hline \multicolumn{3}{|l|}{ Chemical composition* (\%) } \\
\hline Moisture & $12.40^{\mathrm{a}}$ & $12.88^{\mathrm{a}}$ \\
\hline Crude protein & $12.26^{\mathrm{c}}$ & $13.63^{b}$ \\
\hline Lipids & $1.21^{c}$ & $2.77^{b}$ \\
\hline Ash & $0.49^{c}$ & $2.44^{\mathrm{b}}$ \\
\hline Crude fiber & $0.59^{b}$ & $4.53^{\mathrm{a}}$ \\
\hline nitrogen free extract & $85.53^{\mathrm{a}}$ & $76.67^{\mathrm{b}}$ \\
\hline \multicolumn{3}{|l|}{ Vitamins* $(\mathrm{mg} / \mathbf{1 0 0 g})$} \\
\hline Thiamine (vit. $B_{1}$ ) & $1.40^{\mathrm{b}}$ & $7.00^{\mathrm{a}}$ \\
\hline Riboflavin (vit. $\mathrm{B}_{2}$ ) & $0.83^{\mathrm{b}}$ & $1.53^{\mathrm{a}}$ \\
\hline Tocopherol (vit. E) & $0.33^{b}$ & $1.16^{\mathrm{a}}$ \\
\hline \multicolumn{3}{|l|}{ Minerals (mg/100g) } \\
\hline Sodium (Na) & 36.76 & 61.19 \\
\hline Potassium (K) & 126.70 & 537.00 \\
\hline Iron $(\mathrm{Fe})$ & 2.10 & 4.27 \\
\hline Cupper (Cu) & 0.88 & 0.25 \\
\hline Phosphorus (P) & 117.50 & 360.00 \\
\hline Zinc (Zn) & 1.89 & 3.26 \\
\hline Manganese (Mn) & 1.09 & 2.39 \\
\hline Calcium (Ca) & 38.10 & 36.60 \\
\hline Magnesium (Mg) & 16.80 & 107.00 \\
\hline \multicolumn{3}{|l|}{ Dietary fiber (\%) } \\
\hline Total dietary fiber & 4.88 & 19.00 \\
\hline Soluble dietary & 1.78 & 2.30 \\
\hline Insoluble dietary fiber & 3.10 & 16.70 \\
\hline$\beta$-glucan & 0.34 & 8.65 \\
\hline \multicolumn{3}{|l|}{ Phytochemicals* } \\
\hline Total phenols (mg gallic acid/g) & $1.13^{c}$ & $12.58^{\mathrm{a}}$ \\
\hline Total flavonoids (mg catchin/g) & $0.36^{\mathrm{a}}$ & $0.36^{a}$ \\
\hline Antioxidant activity (DPPH) & $5533^{c}$ & $9734^{a}$ \\
\hline
\end{tabular}

* Means followed by different letters in the same column are significant different by Duncan's multiple test $(p<0.05)$

\section{Amino acids content}

Data presented in Table (2) showed the essential amino acid composition (g AA/100 g protein).Barley flour Contained higher amino acid contants compare to wheat flour as could be seen in Table(2) . On the other hand, the wheat flour recorded the highest of some essential amino acids such as, isoleucine tyrosine and phenyl alanine than that in barley flour. Also, concerning of nonessential amino acid (NAA), glutamic acid recorded the highest values of amino acids content for wheat or barley flour (25.21 or $22.27 \mathrm{~g} \mathrm{AA} / 100 \mathrm{~g}$ protein), respectively. An addition it was found that wheat and barley flour contained the relatively highest concentration of methionine+ cysteine and phenylalnine + tyrosin than FAO/WHO scoring pattern being (3.92 and $8.13 \mathrm{~g} / 100 \mathrm{~g}$ protein) for wheat flour and (4.19 and $6.79 \mathrm{~g} / 100 \mathrm{~g}$ protein) for barley flour. Amino acid scores can be used generally to predict protein nutritional value for human.

Table 2. Amino acid composition (g AA/100g protein) and calculated protein biological values of wheat and barley flour

\begin{tabular}{|c|c|c|c|c|c|}
\hline \multirow[b]{2}{*}{ Amino acids } & \multirow{2}{*}{\multicolumn{2}{|c|}{$\begin{array}{cc}\text { Wheat } \\
\text { AASP } & \text { flour } \\
& (72 \% \text { ext }) \\
\end{array}$}} & \multirow[b]{2}{*}{ Barley flour } & \multicolumn{2}{|c|}{ FAW/WHO } \\
\hline & & & & Child & adult \\
\hline \multicolumn{6}{|c|}{ Exssential amino acids (EAA) } \\
\hline Valine & 4.96 & 4.00 & 4.18 & 3.5 & 1.3 \\
\hline Isoleucine & 4.00 & 3.75 & 2.94 & 2.8 & 1.3 \\
\hline Leucin & 7.04 & 5.90 & 5.64 & 6.6 & 1.9 \\
\hline Cystine & & 2.17 & 2.45 & & \\
\hline Methionine & & 1.75 & 1.74 & 2.5 & 1.7 \\
\hline Tyrosin & 4.00 & 3.13 & 2.34 & 6.3 & 1.9 \\
\hline Phenylanine & & 5.00 & 4.45 & 5.6 & 1.6 \\
\hline Lysine & 5.44 & 1.80 & 4.05 & 3.4 & 0.9 \\
\hline Thronine & & 2.30 & 2.91 & 1.9 & 1.6 \\
\hline Histidin & & 2.30 & 2.38 & & \\
\hline Meth + Cyst & 3.52 & 3.92 & 4.19 & & \\
\hline Phen+ Tyrosin & 6.08 & 8.13 & 6.79 & & \\
\hline \multicolumn{6}{|c|}{ Non-essential amino acids (NAA) } \\
\hline Aspartic acid & & 3.75 & 6.09 & & \\
\hline Serine & & 3.58 & 3.18 & & \\
\hline Glutamic acid & & 25.21 & 22.27 & & \\
\hline Glycine & & 3.50 & 3.64 & & \\
\hline Alanine & & 2.70 & 3.64 & & \\
\hline Argenine & & 3.60 & 4.67 & & \\
\hline Proline & & 11.90 & 9.54 & & \\
\hline C-PER & & 1.08 & 1.63 & & \\
\hline CS & & 33.10 & 54.44 & & \\
\hline EAAI & & 60.39 & 66.89 & & \\
\hline BV & & 54.10 & 61.18 & & \\
\hline LAA & & Lysine & Isoleucine & & \\
\hline
\end{tabular}

$\mathrm{C}-\mathrm{PER}=$ Calculated protein efficiency ratio

$\mathrm{CS}=$ Chemical score

$\mathrm{EAAI}=$ Essential amino acid index

$\mathrm{BV}=$ Biological value

LAA = Limiting amino acid

AASP = Amino acid scoring pattern FAO / WHO (1985) 
The amino acid scores demonstrated that wheat flour were deficient in lysine, while barley flour were deficient in isoleucine.

From the results, it could be noticed that the quality of protein parameters (PER, CS, EAAI, BV and $L A A$ ) were indicated that barley flour can be utilized as a good protein source. Therefore, mixing the wheat flour with barley flour under study could give a product with high quality protein. These results were found to be agreed with those obtained by Alu-Datt et al (2012) and Biel and Jacon (2013)

\section{Gluten content and falling number}

Wet gluten and gluten index of wheat flour (72\% ext.) and its blends with 10, 15, 20, 25 and $30 \%$ of barley flour used in the current study were determined and the obtained results were presented in Table (3). The replacement of wheat flour with barley flour caused significantly decreased of wet gluten as the level of replacement increased. The percentage of wet gluten decreased about 8.5, $10.4,13.6,37.5$ and $48 \%$ for wheat flour replacement with $10,15,20,25$ and $30 \%$ of barley flour, respectively compared with control wheat flour. This finding is in harmony with the obtained by Dhingra and Jood (2004). On the other hand, the replacement of wheat flour with 10 and $15 \%$ of barley flour caused slightly decreased of gluten index.

Table 3. Gluten content and falling number of wheat flour and composite flour replacement with barley flour

\begin{tabular}{|c|c|c|c|c|}
\hline $\begin{array}{c}\text { Wheat } \\
\text { flours with } \\
\text { additives }\end{array}$ & $\begin{array}{l}\text { Wet glu- } \\
\text { ten* con- } \\
\text { tent }(\%)\end{array}$ & $\begin{array}{c}\text { Gluten } \\
\text { index* } \\
(\%)\end{array}$ & $\begin{array}{c}\text { Falling } \\
\text { number* } \\
\text { (sec.) }\end{array}$ & $\begin{array}{c}\text { Liquefaction } \\
\text { number }\end{array}$ \\
\hline $\begin{array}{c}\text { Control } \\
\text { sample } \\
\text { (wheat } \\
\text { flour) }\end{array}$ & $31.7 a$ & $95 a$ & $449 a$ & $15.04 b$ \\
\hline $\begin{array}{r}\text { Barley flour } \\
\text { Percentage } \\
\text { flou }\end{array}$ & $\begin{array}{l}\text { ND } \\
\text { of barley } \\
\text { ur }\end{array}$ & ND & $408 a$ & $16.76 a$ \\
\hline $10 \%$ & $29.0 a b$ & $91.1 \mathrm{ab}$ & $445 a$ & $15.19 b$ \\
\hline $15 \%$ & $28.4 a b$ & $85.5 b$ & $449 a$ & $15.04 b$ \\
\hline $20 \%$ & $23.4 b$ & $80.8 b c$ & $448 a$ & $15.08 \mathrm{~b}$ \\
\hline $25 \%$ & $19.8 \mathrm{c}$ & $75.9 c$ & $445 a$ & $15.19 b$ \\
\hline $30 \%$ & $16.5 d$ & $69.1 d$ & $445 a$ & $15.19 \mathrm{~b}$ \\
\hline
\end{tabular}

* Means followed by different letters in the same column are significant different by Duncan's multiple test $(\mathrm{P}<0.05)$. $\mathrm{ND}=$ not determined
Data in the above mentioned Table revealed that, falling number not affected by the addition of barley flour, there were no significant differences $(P>0.05)$ between wheat flour sample and wheat flour replacement with 10, 15, 20, 25 and 30\% barley flour. The falling number values was ranged from 445 to $449 \mathrm{sec}$. for all samples. Also, the liquefaction number was not affected by the addition of barley flour (ranged from 15.04 to 15.19) for all wheat flour samples replacement with barley flour. (Dornez et al 2007).

\section{Rheological properties of dough}

From results presented in Table (4), it could be observed that the replacement levels in the blends of barley flour was increased, the water absorption was increased as compared with control sample (wheat flour $72 \%$ ext.). The increased in water absorption is probably due to the increase in the total protein, fiber and $\beta$-glucan contents of barley flour than wheat flour. These results are in agreement with Skendi et al (2010). On the other hand, it could be noticed that the stability of dough was not affected with the increasing of replacement of barley flour. The dough stability for all sample ranged from 9.0 to $9.5 \mathrm{~min}$. Rieder et al (2012) reported that, the substitution of white wheat flour with barley flour did not lead to any significant differences from the same Table (4) revealed that the degree of weakening values (BU) increased gradually by the increasing levels of barley flour.

The increased in the weakness of the dough may be due to using barley flour which reduced the wheat gluten content (dilution effect) in the blends (Mekhael, 2004)

It could be noticed that from the data presented in Table (4), the resistance to extension of the dough showed not effected by added barley flour to wheat flour. Moreover, the blends contained 15 and $20 \%$ barley flour had higher resistance to extension value (535 and $525 \mathrm{BU}$ ), respectively, than that $(500 \mathrm{BU})$ found in control dough.

On the other hand, it could be observed that the dough extensibility showed a pronounced decrease as the amount of barley flour increase. The percentage of extensibility were decreased about (140 and $120 \mathrm{~mm}$ ) for wheat flour replacement with 10 and $15 \%$ barley flour, respectively. Concerning the dough energy $\left(\mathrm{cm}^{2}\right)$, these values decreased gradually by the increasing of barley flour.

These results are in agreement with mann et al (2005). These observation probably due to $\beta$ - 
glucan which increase the elastic modules of wheat flour dough (Izydorezkyk et al (2001)

Table 4. Farinograph and extensograph parameters of wheat flour dough replacement with different levels of barley flour

\begin{tabular}{|c|c|c|c|c|c|c|}
\hline $\begin{array}{c}\text { Blends } \\
\text { Parameters }\end{array}$ & $\begin{array}{c}\text { Control } \\
\text { sample } \\
(100 \% \\
\text { wheat } \\
\text { flour }\end{array}$ & $\begin{array}{l}90 \% \\
W F+ \\
10 B F\end{array}$ & $\begin{array}{c}85 \% \\
W F+ \\
15 \% \\
B F\end{array}$ & $\begin{array}{c}80 \% \\
W F+ \\
20 \% \\
B F\end{array}$ & $\begin{array}{c}75 \% \\
W F+ \\
25 \% \\
\text { BF }\end{array}$ & $\begin{array}{c}70 \% \mathrm{WF}+ \\
30 \% \mathrm{BF}\end{array}$ \\
\hline \multicolumn{7}{|c|}{ Farinograph parameters } \\
\hline $\begin{array}{l}\text { Water absorp- } \\
\text { tion (\%) }\end{array}$ & 62.0 & 64.0 & 64.7 & 65.8 & 67.1 & 68.0 \\
\hline $\begin{array}{l}\text { Arrival time } \\
\text { (min.) }\end{array}$ & 1.5 & 1.5 & 1.5 & 1.5 & 1.5 & 1.5 \\
\hline $\begin{array}{l}\text { Dough devel- } \\
\text { opment time } \\
\text { (min.) }\end{array}$ & 3.0 & 5.5 & 4.8 & 3.0 & 3.7 & 3.2 \\
\hline $\begin{array}{l}\text { Dough stabil- } \\
\text { ity (min.) }\end{array}$ & 9.5 & 9.5 & 9.0 & 9.0 & 9.2 & 9.5 \\
\hline $\begin{array}{ll}\text { Mixing } & \text { toler- } \\
\text { ance } & \text { index } \\
(\mathrm{Bu}) & \end{array}$ & 35.0 & 25.0 & 23.0 & 23.0 & 26.0 & 20.0 \\
\hline $\begin{array}{l}\text { Dough weak- } \\
\text { ening }(\mathrm{Bu})\end{array}$ & 55.0 & 73.0 & 90.0 & 93.0 & 93.0 & 93.0 \\
\hline \multicolumn{7}{|c|}{ Extensograph parameters } \\
\hline $\begin{array}{l}\text { resistance to } \\
\text { extension "R" } \\
\text { (Bu) }\end{array}$ & 500 & 500 & 535 & 525 & 495 & 505 \\
\hline $\begin{array}{l}\text { Extensulibility } \\
\text { "E" (mm) }\end{array}$ & 150 & 140 & 120 & 105 & 105 & 90 \\
\hline $\begin{array}{l}\text { OIProportional } \\
\text { number (R/E) }\end{array}$ & 3.33 & 3.57 & 4.46 & 5.00 & 4.71 & 5.61 \\
\hline $\begin{array}{l}\text { Strength of } \\
\text { dough (ener- } \\
\text { gy) }\left(\mathrm{cm}^{2}\right)\end{array}$ & 100 & 97 & 87 & 76 & 70 & 60 \\
\hline
\end{tabular}

$\mathrm{WF}=$ Wheat flour

$\mathrm{BF}=$ Barley flour

\section{Physical measurements of fresh pan bread}

Results in Table (5) showed that, bread weight of pan bread prepared by added $20 \%$ barley flour (20\% BB) was higher than $15 \% \mathrm{BB}, 10 \%$ and WB (control samples for bread prepared with or without improver). The increasing of bread weight may be to the increase fiber and $\beta$-glucan content in barley flour as presented in Table (1) which characterized by higher water holding capacity as mentioned by Skendi et al (2010). On the other hand, the volume of $10 \%$ BB and $15 \%$ BB was decreased about 5.6 and $9.8 \%$ or 5.3 and $16.1 \%$ in bread prepare with or without improver, respectively compared to control sample. This data confirmed the results of rheological dough properties (Table 4) and also are in agreement with Izydorczk et al (2001). Also, the reduction in loaves volume may be the dilution of wheat gluten as a result of addition of barley flour, plus the increased in fiber content specially $\beta$-glucan as presented in Table (1). On the other hand, the volume of $10 \% \mathrm{BB}$ and $15 \%$ BB prepared by added improver higher than WB without improver, these values were 1133 and $1082 \mathrm{~cm}^{3}$ compared to WB $924 \mathrm{~cm}^{3}$. Also, specific volume of $10 \%$ BB or $15 \%$ BB prepared by added improver higher than WB without improver (control sample).

Table 5. Physical properties of pan bread prepared by partial replacement of wheat flour (72\% ext.) with barley flour

\begin{tabular}{|c|c|c|c|c|c|c|}
\hline \multirow[t]{2}{*}{ Bread } & \multicolumn{2}{|c|}{$\begin{array}{c}\text { Loaf } \\
\text { weight }^{*}(\mathrm{~g})\end{array}$} & \multicolumn{2}{|c|}{$\begin{array}{l}\text { Loaf vol- } \\
\text { ume }^{*}\left(\mathrm{~cm}^{3}\right)\end{array}$} & \multicolumn{2}{|c|}{$\begin{array}{l}\text { Specific } \\
\text { volume } \\
\left(\mathrm{cm}^{3} / \mathrm{g}\right)\end{array}$} \\
\hline & A & B & A & B & A & B \\
\hline $\begin{array}{l}\text { Control sample }(100 \% \\
\text { wheat flour (WF) }\end{array}$ & $272^{a b}$ & $271^{c}$ & $924^{\mathrm{a}}$ & $1200^{a}$ & $3.39^{a}$ & $4.41^{a}$ \\
\hline $\begin{array}{l}90 \% \mathrm{WF}+10 \% \mathrm{BF} \\
(10 \% \mathrm{BB})\end{array}$ & $272^{a b}$ & $273^{b c}$ & $875^{\mathrm{b}}$ & $1133^{b}$ & $3.22^{b}$ & $4.15^{b}$ \\
\hline $\begin{array}{l}85 \% W F+15 \% B F \\
(15 \% B B)\end{array}$ & $272^{\mathrm{ab}}$ & $273^{b c}$ & $775^{d}$ & $1082^{c}$ & $2.84^{d}$ & $3.96^{c}$ \\
\hline $\begin{array}{l}80 \% W F+20 \% B F \\
(20 \% B B)\end{array}$ & $275^{\mathrm{a}}$ & $279^{a}$ & $700^{a}$ & $725^{\mathrm{e}}$ & $2.53^{\mathrm{e}}$ & $2.59^{\mathrm{e}}$ \\
\hline
\end{tabular}

$\mathrm{WF}=$ Wheat flour

$A=$ Pan bread made without improver

$\mathrm{B}=$ Pan bread made by added bread improver

\section{Sensory evaluation of pan bread samples}

The results in Table (6) showed that there were no significant differences $(P<0.05)$ in all the organoleptic properties of produced pan bread without improver between the control sample (WB1) and bread sample contained $10 \%$ barley flour $(10 \%$ BB1) except the taste. On the other hand, the addition of bread improver, there were no significant differences $(\mathrm{P}<0.05)$ in all the organoleptic properties between the control sample (WB1) and bread sample contained 10 or $15 \%$ barley flour $(10 \%$ BB2 or $15 \%$ BB2), except the grain. The total score of WB1 was 93.71, this value decrease about $4.3 \%$ for pan bread containing $10 \%$ barley flour (10\% BB1) comparing to WB1. Also, the total score of WB2 was 94.10 , this value only decreased about 1.5 or 4.0 for $(10 \%$ BB2 or $15 \%$ BB2), respectively. 
Table 6. Organoleptic evaluation of wheat fresh pan bread rise composite flour with and without bread improver.

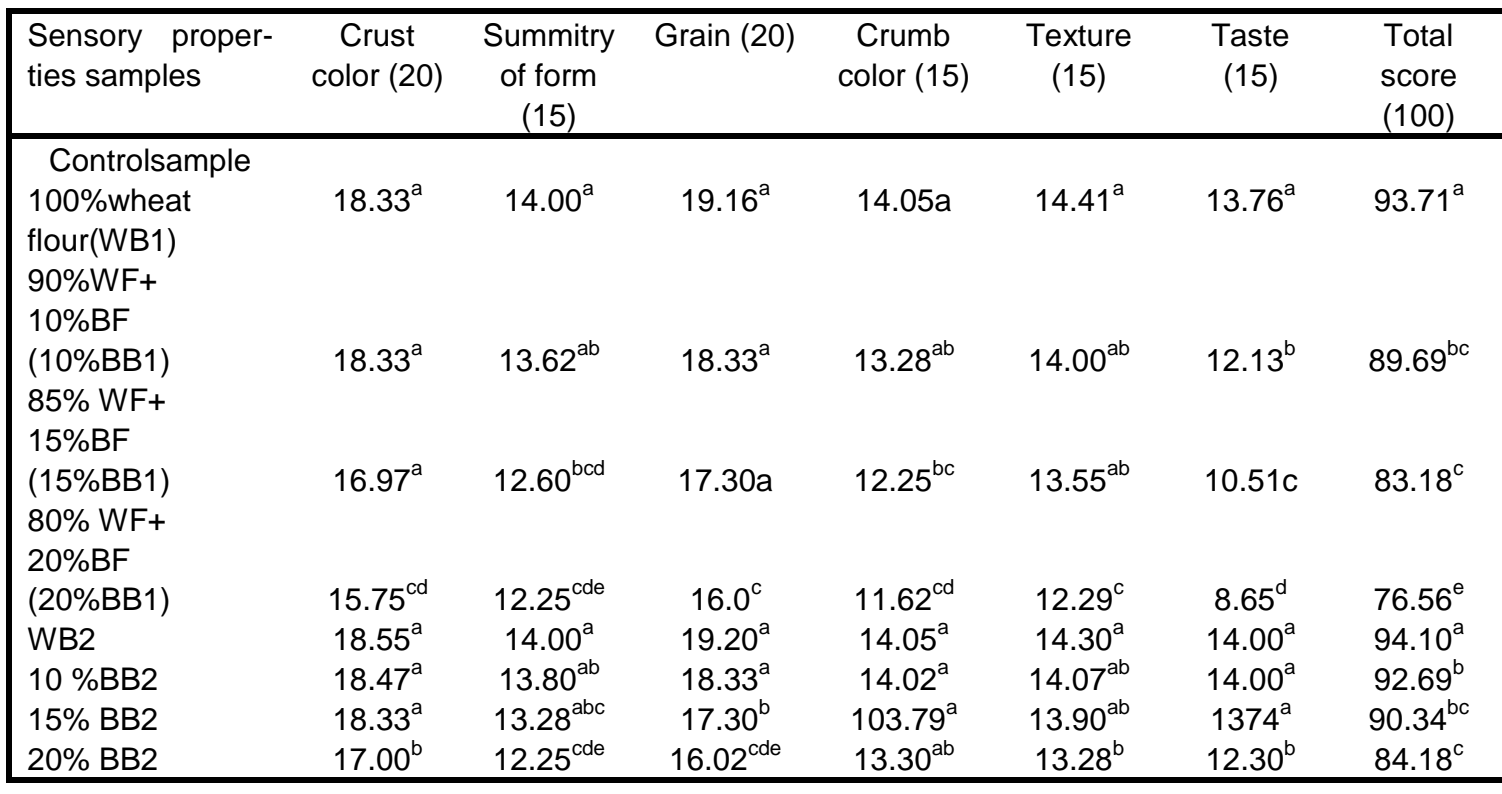

$\mathrm{WF}=$ Wheat flour $\quad \mathrm{BF}=$ Barley flour

$\mathrm{BB} 1=$ Pan bread made without improver

BB2 $=$ Pan bread made by added bread improver

* Means followed by different letters in the same column are significant different by Duncan's multiple test $(p<0.05)$.

These results are in agreement by Bhatty (1986) and El-Yamlahi and Qussine (2013). Generally, it could be concluded that the pan bread produced by replacement with $10 \%$ barley flour (89.69) or (92.69 and 90.34) gave bread loaves more sensory acceptable rather than the pan bread produced by added $20 \%$ barley flour.

Texture profile analysis of pan bread as affected by addition of barley flour to wheat flour (72\% ext.)

Pan bread texture was determined as hardness, cohesiveness, gumminess, springiness, chewiness using a TPA texture profile analyzer. The results of texture profile analysis of pan bread samples are shown in Table (7). As can be seen, additional of barley flour at different ratios 10, 15, and $20 \%$ in the formulation of the bread samples affected the textural properties of the produced bread.

Hardness is an important factor in baking products since it is strongly correlated with consumer perception of bread freshness (Olaoye et al 2006). Hardness of bread were increased by increasing the level of addition of barley flour as compared to bread made from wheat flour (control sample). Lower values of hardness were recorded to bread sample made from wheat flour $(501 \mathrm{~g})$, while this value was increased to 518,770 and $1178 \mathrm{~g}$ for the fresh pan bread replacement with 10, 15 and $20 \%$ barley flour, respectively.

Also, from the data presented in Table (7) showed that the freshness of pan bread were decreased for all samples by increasing the storage period at room temperature.

The internal resistance of bread crumb is evaluated by cohesiveness which is a characteristic of mastication. The replacement of wheat flour with barley flour is not affecting of cohesiveness of bread at zero time after baking.

Gumminess of bread samples were increased by increasing the level of addition of barley flour compared to bread made from wheat flour $(72 \%$ ext.) replacement with barley flour, the percentage of gumminess of bread samples was increases about $4.0 \%$ for the bread replacement with 10 or $15 \%$ barley flour by increasing storage period. Chewiness is one of the texture parameters easily correlated with sensory analysis (Gallagher et al 2003). It is related to the work needed to chew a solid sample such as bread to a steady state of 
Table 7. Texture profile parameters of pan bread as affected by addition of barley flour and storage of different times at room temperature $\left(25^{\circ} \pm 5^{\circ} \mathrm{C}\right)$

\begin{tabular}{|c|c|c|c|c|c|}
\hline $\begin{array}{c}\text { Parameters } \\
\text { Storage period } \\
\text { (hour) }\end{array}$ & $\begin{array}{l}\text { Hardness } \\
\text { (g) }\end{array}$ & Cohesiveness & $\begin{array}{c}\text { Gumminess } \\
\text { (g) }\end{array}$ & $\begin{array}{c}\text { Chewiness } \\
(\mathrm{mg})\end{array}$ & $\begin{array}{c}\text { Springiness } \\
(\mathrm{mm})\end{array}$ \\
\hline \multicolumn{6}{|c|}{ pan bread made from $100 \%$ wheat flour ( $72 \%$ ext.) } \\
\hline 0 & 501 & 0.80 & 407 & 33.30 & 0.48 \\
\hline 24 & 793 & 0.78 & 635 & 58.30 & 0.49 \\
\hline 48 & 1314 & 0.62 & 863 & 74.30 & 0.27 \\
\hline 72 & 1545 & 0.58 & 964 & 83.70 & 0.26 \\
\hline \multicolumn{6}{|c|}{ Pan bread made from wheat flour replacement with $10 \%$ barley flour } \\
\hline 0 & 518 & 0.80 & s423 & 38.50 & 9.27 \\
\hline 24 & 822 & 0.73 & 623 & 56.50 & 9.26 \\
\hline 48 & 1078 & 0.67 & 758 & 68.50 & 9.21 \\
\hline 72 & 1075 & 0.67 & 758 & 95.90 & 8.87 \\
\hline \multicolumn{6}{|c|}{ Pan bread made from wheat flour replacement with $15 \%$ barley flour } \\
\hline 0 & 770 & 0.80 & 423 & 38.50 & 9.28 \\
\hline 24 & 1612 & 0.63 & 1055 & 84.20 & 8.62 \\
\hline 48 & 2116 & 0.62 & 1370 & 107.40 & 7.99 \\
\hline 72 & 2570 & 0.52 & 1426 & 116.80 & 8.35 \\
\hline \multicolumn{6}{|c|}{ Pan bread made from wheat flour replacement with $20 \%$ barley flour } \\
\hline 0 & 1178 & 0.02 & 646 & 59.60 & 9.41 \\
\hline 24 & 1465 & 0.71 & 1092 & 101.60 & 9.49 \\
\hline 48 & 1896 & 0.67 & 1336 & 197.10 & 8.94 \\
\hline 72 & 1770 & 0.78 & 1450 & 134.90 & 9.49 \\
\hline
\end{tabular}

swallowing, crumb chewiness is a product of crumb hardness, chewiness of bread samples were increased by increasing the level of addition of barley flour as compared to bread made from wheat flour (control sample). Lowering values of chewiness were recorded to bread samples made from wheat flour replacement with 15 and $20 \%$ barley flour. On the other hand, chewiness of all bread samples was increased gradually during storage of bread up to 72 hours at room temperature.

Springiness is a measurement of how much the bread crumb springs back after being compressed once and it can be defined as the elasticity of the bread crumb, it is also an important parameters to determine the staling of bread in Table (7) the results of springiness indicated that when the substitution level of barley flour increased, the bread required more time to recover its shape. Also, the springiness of bread was gradually decreased for all samples during storage of bread at room temperature.

\section{REFERENCES}

A.A.C.C. 2000. Approved Method of the AACC. $10^{\text {th }}$ ed., American Association of Cereal Chemists. Inc. St., Paul, Minnesota, USA.

A.O.A.C. 2000. Official Methods of Analysis, $17^{\text {th }}$ ed., Association of Official Analyical Chemists International. Gaithersburg, Maryland, USA.

Abdelghafar, Ranya. F., Mustafa, A.l., Ibrahim, A.M.H. and Krishnan, P.G. 2011. Quality of bread from composite flour of sorghum and hard white wheat. Advance Journal of Food Science and Technology. 3(1), 9-15.

Alsmyer, R.H. Cunningham, A.E. and Happich, M.L. 1974. Equations predict PER from amino acid analysis. Food Technol. 28, 34.

Aludatt, M.H., Taha, R., Khalil, E., Inteaz, A., Mohamed, A.A., Ali, A., Nather M. and Mohamad, M.A. 2012. Effects of barley flour and barley protein isolated on chemical. Functional, nutritional and biological properties of pita bread. Food Hydrocolloids 28, 135-143. 
Bhatty, R.S. 1986.Physicochemical and functional(bread making) properties of hulless barley fractions. Cereal Chem. 63, 31-35.

Biel, W. and Jacon, E. 2013. Chemical composition and nutritive value of spring hulled barley varieties. Bulgarian. J. of Agric. Sci., 19(4), 721-727.

Bxter, J.H. 1996. Amino Acids. In. "Handbook of food analysis". pp. 179-228. Vol.1 M.L. Nollet (ed.). Marcel Dekker, Inc., New York, USA.

Carr, J., Glatter, S., Jeraci, A. and Lewis, B. 1990. Enzymic determination of $\beta$-glucan in cereal based food products. Cereal Chem., 67(3), 226-229.

Cavallero, A., Empilli S., Brighenti, F. and Stanca, A.M. 2002. High (1-3), 1-4)-B-glyucan barley fraction in bread making and their effects on human glycemic response. J. Cereal Sci. 36(1), 59-66.

Dewethinck, F., Van Bockstade B. and Van de Walle, J. 2008. Nutritional value of bread: Influence of processing, food interaction and consumer perception, J. Cereal Sci., 48, 243257.

Dhingra, S. and Jood, S. 2001. Organoleptic and nutritional evaluation of wheat breads supplemented with soybean and barley flour. Food Chem. 77, 479-488.

Dhingra, S. and Jood, S. 2004. Effect of flour blending on functional, baking and organoleptic characteristics of bread. International Journal of Food Science and Technology, 39, 213222.

Dornez, E., Gebruers, K., Cuyvers, S., Delcour, J.A. and Courtin, C.M. 2007. Impact of wheat flour-associated endoxylanases on arabinoxylan in dough after mixing and resting. J. Agric. Food.Chem., 55(17), 7149-7155.

El-Yamlahi, A. and Ouhssine, M. 2013. Utilization of barley (Hordeum vulgare L.) flour with common wheat (Triticum aestivum L.) flour in bread-making. Annals of Biological Research, 4(2), 119-129.

FAO/WHO, 1973. Adhoc Expert Committee. Energy and protein requirements: Report of a joint FAO/WHO adhoc expert Committee, Rome, 22 March- 2 April, 1971.

Gallagher,E.; Gormley,T.R and Arendt,E.K .2003. Crust and crumb characteristic of glutenfree bread.J.Food Eng., 56,153-161.

Hwang, E.S. and Dothi, N. 2014. Effect of extraction and processing methods on antioxidant compound contents and radical scavenging ac- tivities of laver (Porphyra tenera). Preventive Nutrition and Food Science, 19, 40-48.

Izydorczyk, M.S., Hussain, A. and McGregort, A.W. 2001. Effect of barley and barley components on rheological properties of wheat dough. J. Cereal Sci, 34, 251-260.

Lupton J.K., Robinson, M.C. and Morin, J.L. 1994. Cholesterol-lowering effect of barley bran flour and oil. Journal of the American Dietetic Association, 1,65-70.

Maiya, J.K.,Shwetha, B.G. and Indrani, D. 2013. Effect of barley flour on rheological characteristics of dough, organoleptic, nutritional and storge characteristics of south Indian parotta.Int. J.Food.Sci.Technol., 21(1), 24-32.

Manach, C., Scalbert, A., Morand, C., Remesy, C. and Jimenez, L. 2004. Polyphenols: food source and bioavailability. American Journal of Clinical Nutrition, 79, 727-747.

Mann, G., Leyne, E., Li, Z. and Morell M.K. 2005. Effects of a novel barley, Himalaya 292 on rheological and bread making properties of wheat and barley doughs. Cereal Chem., 82(6), 626632.

Mekhael, E.K. 2005. Biochemical and Technological Studies on Balady Bread made from Durun wheat mixed with some cereals and cereal by products. M.Sc. Thesis, Cairo Univ., Egypt.65-67.

Miller, J.C. 1994. Importance of glycemic index in diabetes. American Journal of Clinical Nutrition.59, 747-752.

Newman, C.W. and Newman, R.K. 2006. A brief history of barley food. Cereal Foods World. 51, 4-7.

Olaoye, O.A.A., Onilude, A.A. and Idown O.A. 2006. Quality characteristics of bread produced from composite flours of wheat, plantain and soybeans. Afr. J. Biotechnol. 5, 1102-1106.

Oser, B.L. 1959. An integrated essential amino acid index for predicating the biological values of proteins in "Protein and amino acid nutrition, Albanese, A.A. (Ed.), Academic Press, NY, USA.

Prosky, L.; Georg, N.A., Schweizer, T.F., Devries, J.W. and Furda, I. 1998. Determination of insoluble, soluble, and total dietary fiber in foods and food products: inter laboratory study. J. Assoc. off. Anal. Chem., 71(5),10171023.

Quinde-Axtell, Z. and Baik B.K. 2006. Phenolic compounds of barley grain and their implication in food product discoloration. J. of Agric. and Food Chemistry. 54(26), 9978-9984. 
Rieder, A., Holtekjolen, A.K., Sahlstrom, S. and Moldestad, A. 2010. Effect of barley and Oat flour types and sour doughs on dough rheology and bread quality of composite wheat bread. J. Cereal Sci., 55, 44-52.

Salem, E.M. 2005. Quality attributes of macaroni substituted with barley meal. Egyptian J. of Nutr, 20(2), 25-43.

Skendi, A., Biliaderis, C.G., Papageorgioy, M. and Izydorczk, M.S. 2010. Effects of two barley B-glucan isolates on wheat flour dough and bread properties. Food Chem., 119, 11591167.

SPSS, 2000. Statistical package for Social Sci. SPSS for Winds, Version 19, SPSS Inc., Chicago, IL,USA.
Waller, R.A and Duncan D.B. 1969. A bays rule for the symmetric multiple comparison problems. J. of the American Statistical Association., 67, 253-267.

Zhao, H., Fan, W., Dong J., Lu, J., Lin Y., Long W. 2008. Evaluation of antioxidant activities and total phenolic contents of typical malting barley varieties .Food Chem., 107, 296-304.

Zilic, S.; Serpen, A.; Akillioglu, G.; Jankovic, M. and Gokmen, V. 2012. Distributions of phenolic compounds. Yellow pigments and oxidative enzymes in wheat grains and their relation to antioxidant capacity of bran and dehranned flour. J. Cereal Sci., 56, 652-658 